\title{
The effect of 4 weeks high-intensity interval training (HIIT) on the content of downstream and upstream mTORC1 pathways gastrocnemius muscle of type 2 diabetic rats
}

\author{
Golnaz Faezi ${ }^{1}$, Mohammad Sherafati Moghadam ${ }^{2}$, Saeedeh Shadmehri ${ }^{3}$, Mohammad Fathalipour ${ }^{4}$ \\ ${ }^{I}$ Faculty Member of Kharazmi University, Faculty of Physical Education and Sport Sciences, Kharazmi University, \\ Tehran, Iran \\ ${ }^{2}$ Department of Pure and Basic Science, Hashtgerd Branch, Islamic Azad University, Alborz, Iran \\ ${ }^{3}$ Department of Physical Education and Sport Science Yadegar-e-Imam Khomeini (RAH) Shahre-rey Branch, Islamic \\ Azad University, Tehran, I. R. Iran. \\ ${ }^{4}$ Assistant Professor, Department of Pharmacology, Faculty of Pharmacy, Hormozgan University of Medical Sciences, \\ Bandar Abbas, Iran
}

\begin{abstract}
Background: The pathway of mTORC1 is one of the most important pathway in protein synthesis, and type 2 diabetes and insulin resistance can lead to inhibit this pathway. The aim of this study was to investigate the effect of 4 weeks high-intensity interval training (HIIT) on the content of downstream and upstream mTORC1 pathways in gastrocnemius muscle in type 2 diabetic rats.

Materials and methods: In this experimental study, 16 Sprague-Dawley male rats (with mean weight of 250 \pm 20 gr) were selected and after induction of diabetes by streptozotocin and nicotinamide, the rats were randomly assigned into two groups, including diabetic HIIT training and diabetic control. The experimental group performed 4 days a week the exercise training for 4 weeks, while the control group did not have any training program. Independent T-test was used to analyze the data.

Results: A significant change was not observed in the total content of AKT1 proteins $(p<0.31)$, P70S6K1 $(\mathrm{p}<0.69)$ and 4EBP1 $(\mathrm{p}<0.84)$ in the HIIT training group compared to the control group, but the total protein content of mTOR $(p<0.02)$ and the form of phosphorylation of AKT1 $(p<0.03)$, mTOR $(p<0.03)$, P70S6K1 $(p<0.02)$ and 4EBP1 $(p<0.009)$ proteins showed significant increase in training group compared to the control group.

Conclusion: The HIIT training can probably activate the pathway of AKT1/mTOR/P70S6K1 and AKT1/mTOR/4EBP1 in the mTORC1 pathway; therefore, the HIIT training can lead to protein synthesis or muscle hypertrophy through this pathway in the gastrocnemius muscle of the trained rats

Keywords: Gastrocnemius muscle, High-intensity interval training, mTORC1 pathway, Type 2 diabetes.

Cited as: Faezi G, Sherafati Moghadam M, Shadmehri S, Fathalipour M. The effect of 4 weeks high-intensity interval training (HIIT) on the content of downstream and upstream mTORC1 pathways gastrocnemius muscle of type 2 diabetic rats. Medical Science Journal of Islamic Azad University, Tehran Medical Branch 2020; 30(2): 120-127.
\end{abstract}

Correspondence to: Saeedeh Shadmehri

Tel: +989123145412

E-mail: saeedehsh61@gmail.com

ORCID ID: 0000-0002-5000-4427

Received: 27 Apr 2019; Accepted: 21 Jul 2019 
مجله علوم يزشكى دانشگاه آزاد اسلامى

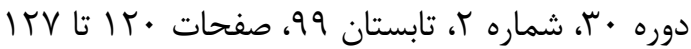

\title{
تاثير F هفته تمرين HIIT بر ميزان پروتئينهاى ياييندست و بالادست مسير r در عضله دوقلوى موش هاى صحر ايى مبتلا به ديابت نوع TORC1
}

\author{
كلناز فائزى'، محمد شرافتى مقدمّ، سعيده شادمهرى"، محمد فتحعلى يور
}

$$
\begin{aligned}
& \text { 'عضو هيات علمى دانشكاه خوارزمى، دانشكده تربيت بدنى و علوم ورزشى، دانشگاه خوارزمى، تهران، ايران } \\
& \text { لَ }
\end{aligned}
$$

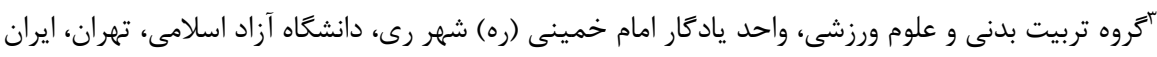

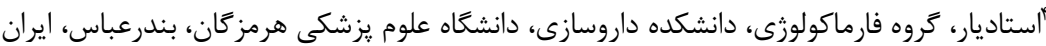

سابقه و هدف: مسير mTORC1 يكى /ز مسيرهاى مهمر درون سلولى در سنتز بروتئين /ست. در بيمارى ديابت نوع r و مقاومت به

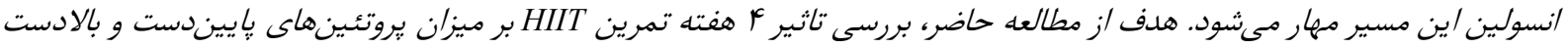

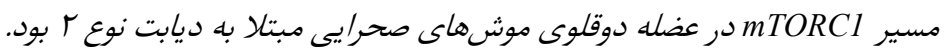

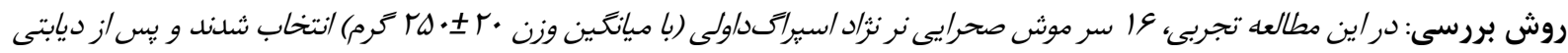

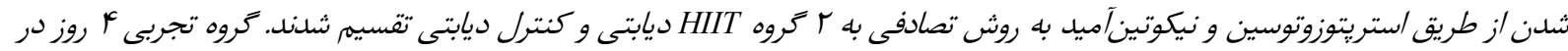

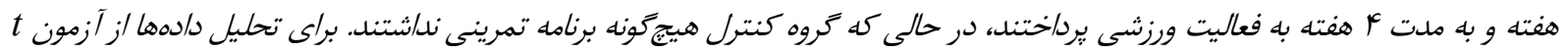
مستقل /ستفاده شد.

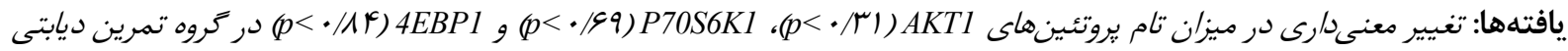

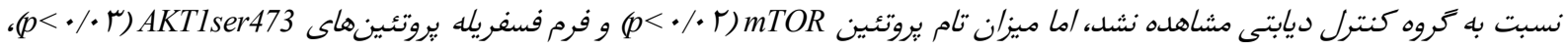

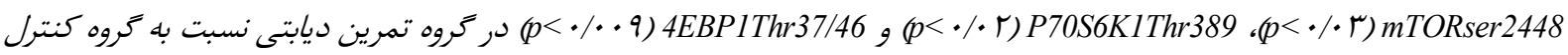
ديابتى افزايش معنى دارى رانشان داد. نتيجه گيرى: تمرين HIIT مت تواند مسيرهاى AKT1/mTOR/P70S6K1 و AKT1/mTOR/4EBP1 را در مسير نتيجه، تمرين HIIT/ز طريق /ين مسير مىتواند موجب سنتز بروتئين يا هيبرتروفى عضلاتى در عضله دوقلوى موش هاى تمرين كرده شود.

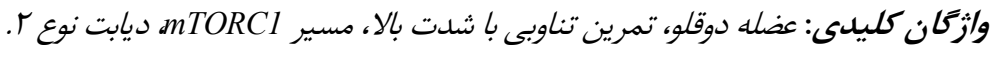

تعادل دو فرآيند يويا، سنتز و تجزيه بروتئين عضلانى اسكلتى

مقدمه

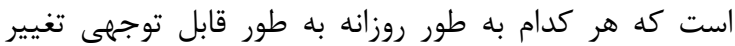

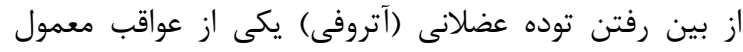

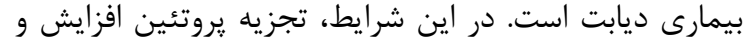

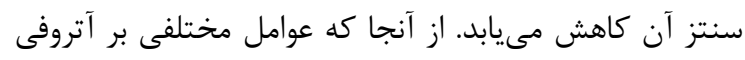

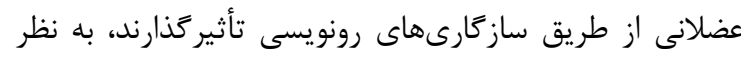
عضله اسكلتى بافت بسيار تغييريذيرى است كه توانايى رشد و

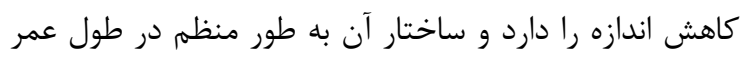
تغيير مى كند. كنترل هموستاز عضلانى اسكلتى از طريق

آدرس نويسنده مسئول: تهران، دانشگاه آزاد اسلامى گروه تربيت بدنى و علوم ورزشى، واحد يادكار امـام خمينى (ره) شهر رى، سعيده شادمهرى (email: saeedehsh61@gmail.com) ORCID ID: 0000-0002-5000-4427

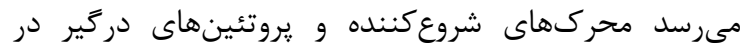
تاريخ دريافت مقاله: 


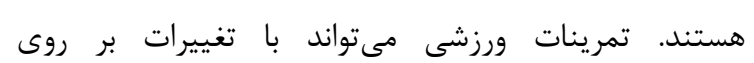

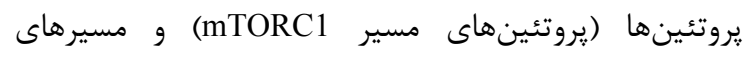

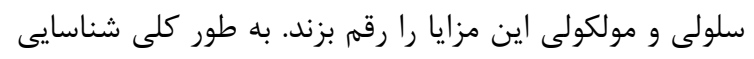

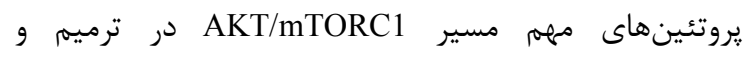
جلوگيرى از آتروفى عضلانى و ساير عوارض با بيمارى ديابت اين فرضيه را مطرح مى كند كه تغيير در ميزان اين يروتئينها احتمالاً از طريق فعاليت ورزشى امرى مهرم است كه مه بايد

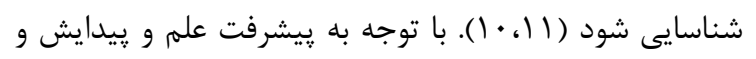
كشف روشها و فعاليتهاى ورزشى مدرن اثرات اين روشها

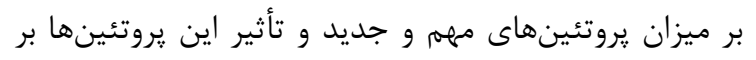

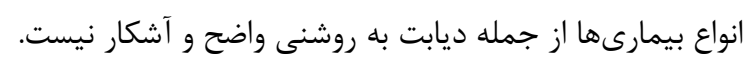

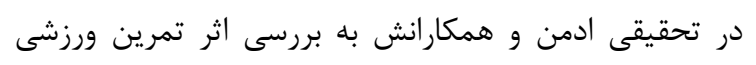

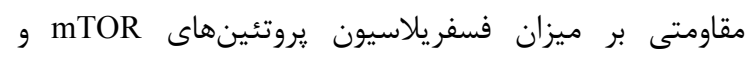

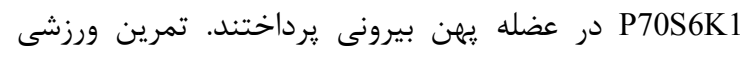

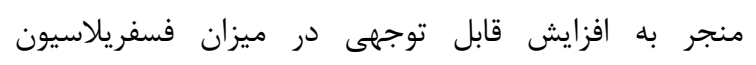
يروتئينهاى mTOR و P70S6K1 شده بود ( I I). در تحقيق ديخر كامرا و همكارانش ميزان يروتئينهاى AKT،

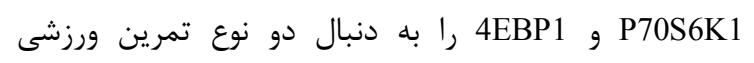

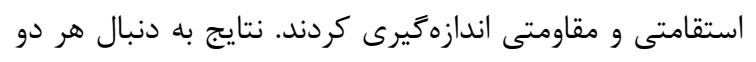
فعاليت ورزشى استقامتى و مقاومتى افزايش معنى دارى را در

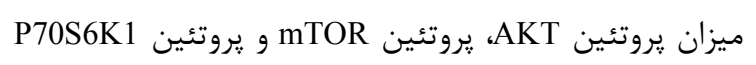

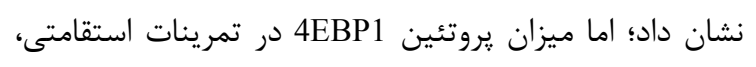

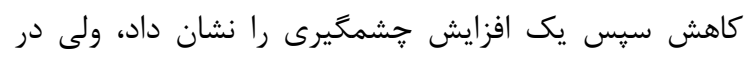

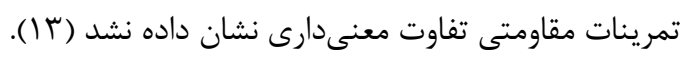

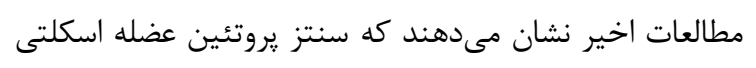
در ياسخ به انواع فعاليتهاى بدنى (مقاومتى و استقامتى)

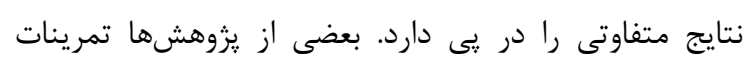

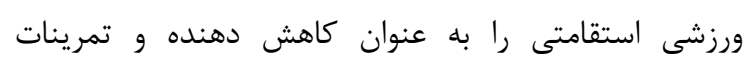
مقاومتى را به عنوان افزايشدهنده توده عضلانى در نظر

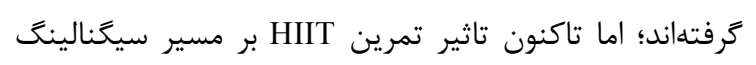

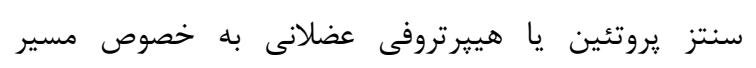

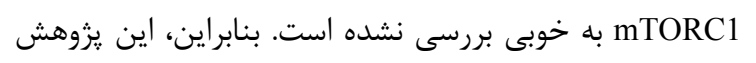

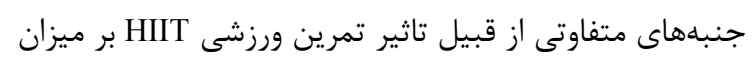
يروتئينهاى بالادست و ياييندست مسير mTORC1 در عضله دوقلو را بررسى مى كند تا اطلاعات يايه و سلولى و مولكولى در خصوص نقش اين يروتئينها در مسير MTORC1 و و تأثير

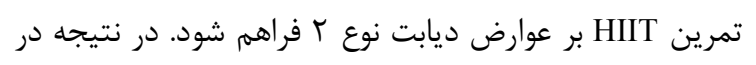
صورت مثبت بودن نتايج اين يثوهش، ميىتواند مورد استفاده

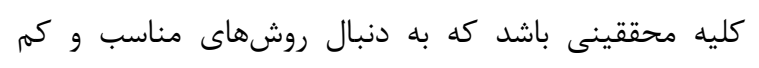

مسيرهاى سنتز از مكانيزمهاى اصلى سيگنالينگ در از دست

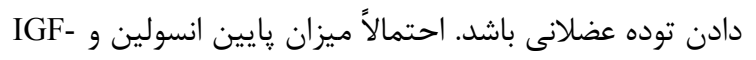

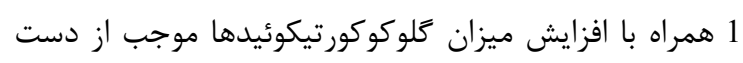
دادن يروتئين عضلانى در بيمارى ديابت مىشود (r).

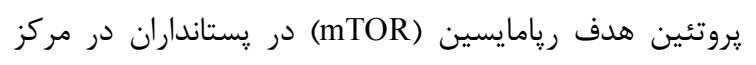
تنظيم سنتز يروتئين عضله اسكلتى قرار دارد. يروتئين

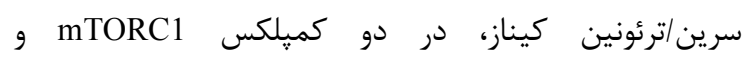
mTORC2 قرار دارد و در هر يك نقش انحصارى دارد (r) دارين. نقش mTOR در كميلكس mTORC1 تنظيم سنتز يروتئين و رشد، سنتز يروتئين ريبوزومى، تنظيم جرخه سلولى، اتوفازى و

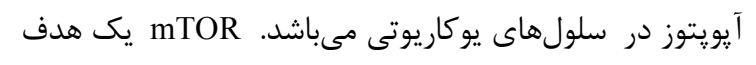

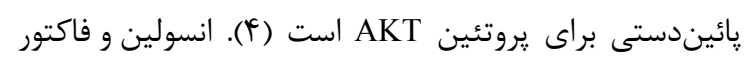

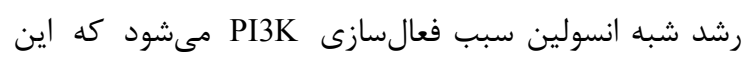
فعالسازى منجر به فسفريلاسيون AKT مى

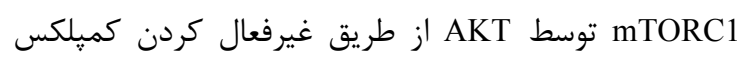
mTORC1 صورت مى $\mathrm{TSC1} 1 / 2$ يروتئينهاى ياييندست آن يعنى

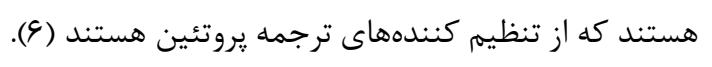

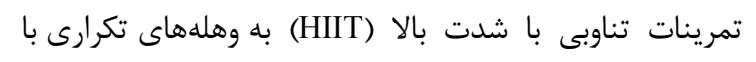

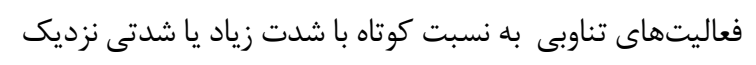

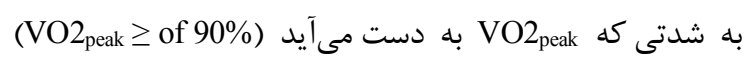

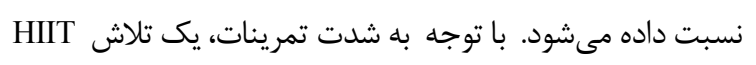

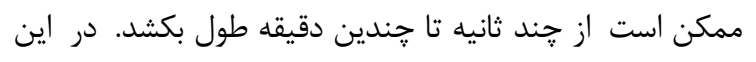

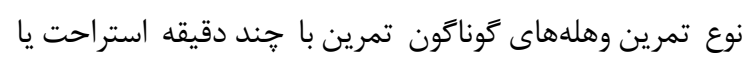

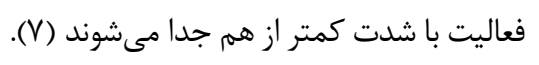

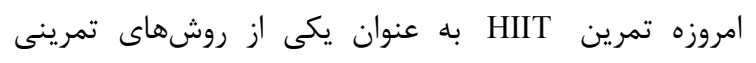

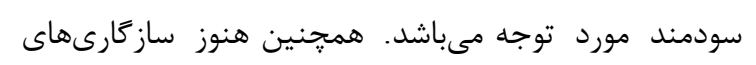

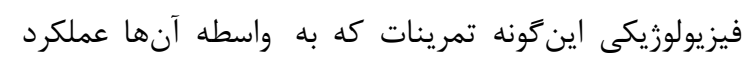

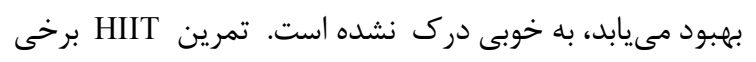

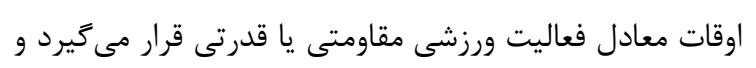
در جندين مطالعه مشخصشده است كه منجر به تغييراتى در

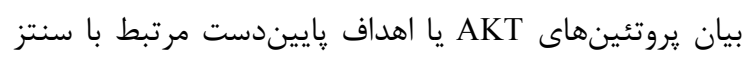

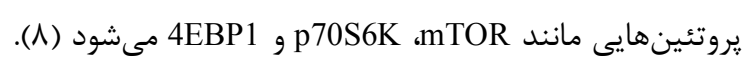
نتايج تمرينات HIIT بر فعاليت mTORC1 در افراد ديابتى و

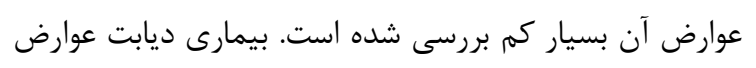

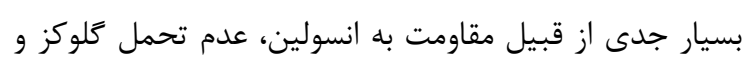
افزايش و كاهش وزن براى شخص مبتلا دارد كه مى مى فواند

زندكى شخصى را تحتالشعاع خود قرار دهد (9، ب). با توجه به اين عوامل، فيزيولوزيستهاى ورزشى به به دنبال تأثير

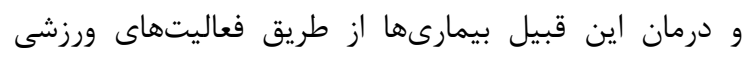


كنترل هيج گَونه برنامـه تمرينـى نداشـتند. مـوشهـاى صـحرايى هيجگ گونه درمانى با انسولين را در طول دوره يزوهش نداشتند.

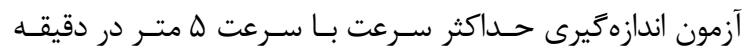
شروع و هر ب دقيقه سرعت تردميل ه متر در دقيقه افزايش يافت

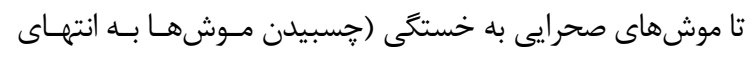

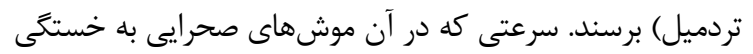
رسيدند، به عنوان حداكثر سرعت در نظر زرفته شد (IV).

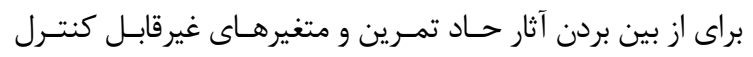

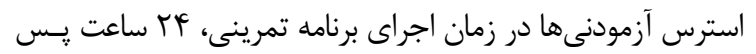

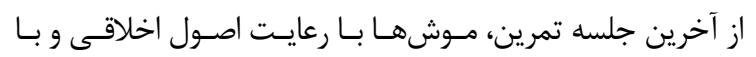

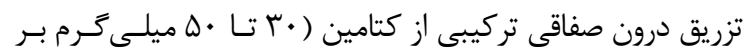

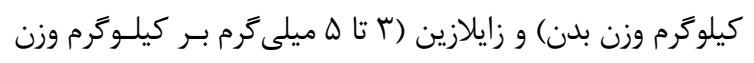

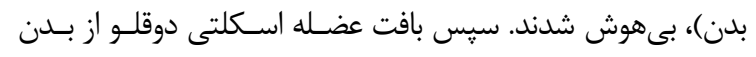

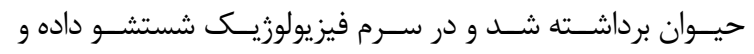

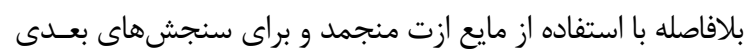

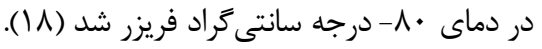

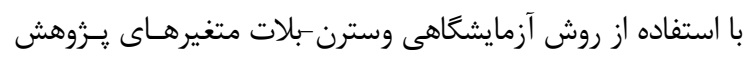

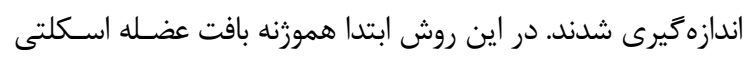

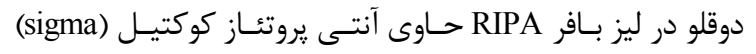

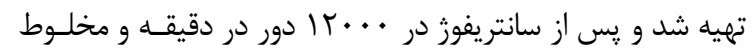

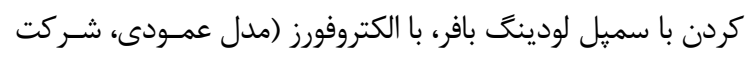

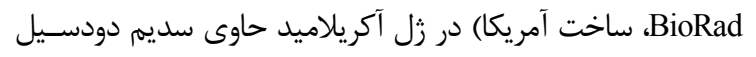
سولفات (Sodium dodecyl sulfate; SDS) تفكيك شدند. بعـد از

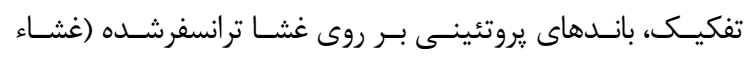
ديفوريسد يلسىوينيليـدين Polyvinylidene difluoride (PVDF)

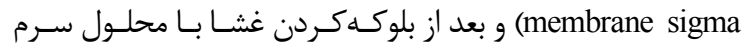
آلبومين كاوى س درصد به مدت يك سـاعت در دمـاى آزمايشـعاه

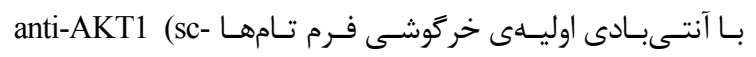
anti-P70S6K1 (Sc- anti-mTOR (Sc-1550-R) ،135829)

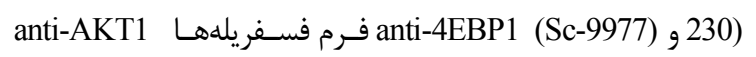
anti-P70S6K1 (Sc- anti-mTOR (Sc-293133)، (sc-52940)

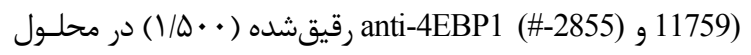

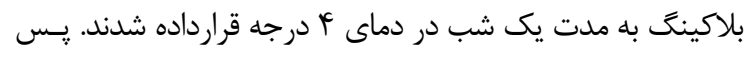

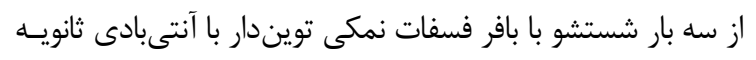

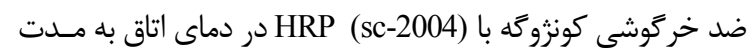

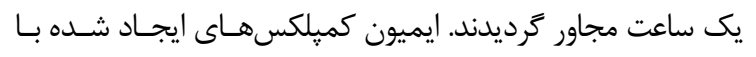

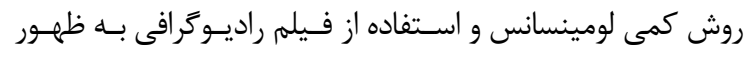

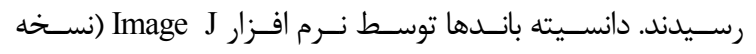

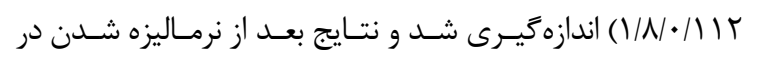

عارضه مانند تمرين ورزشى HIIT براى برطرف نمودن عوارض ناشى از بيمارى ديابت از جمله آتروفى عضلانى هستند.

\section{مواد و روشهها}

اين يزوهش تجربى بـنيادى بـهـ صـورت گــروه آزمـايش و كنتـرل

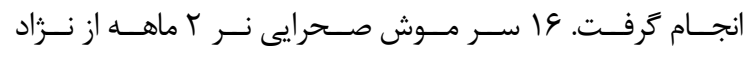

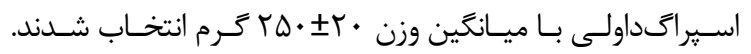

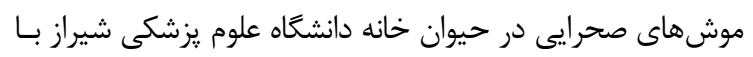

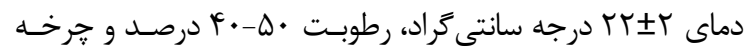

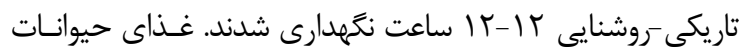
به صورت آزادانه و اسـتاندارد مخصـوص حيوانـات آزمايشـعاهى از

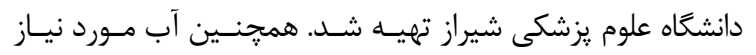

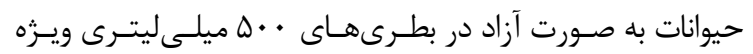

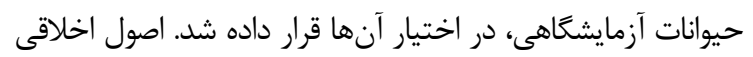

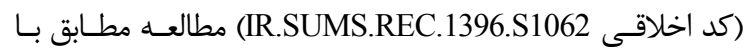

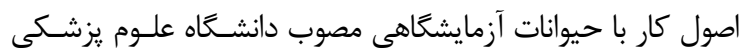
شيراز مورد توجه قرار زرفت. براى ايجاد ديابت در مـوشهــا، محلـول استريتوزوتوسـين (STZ)

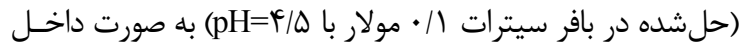

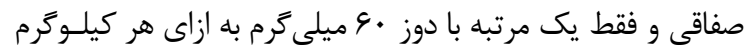

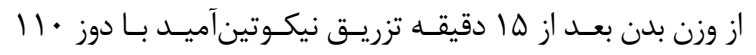

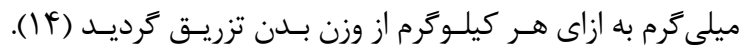

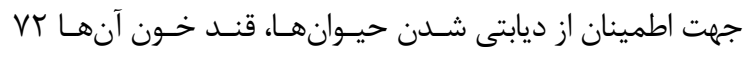

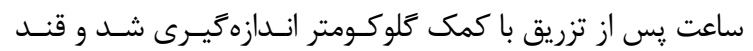

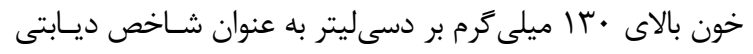

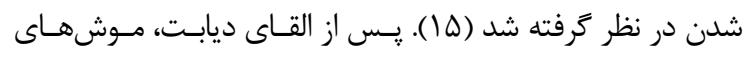

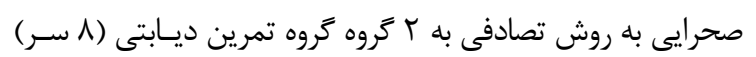
و كنترل ديابتى (1 سر) تقسيهم شدند.

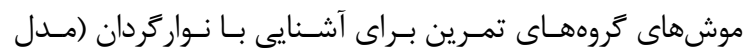

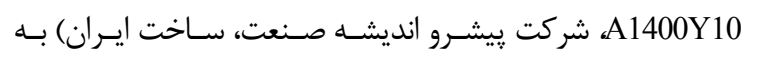
مدت يك هفته با سرعت ه نا • ا متر بـر دقيقـه، روى نـواركردان

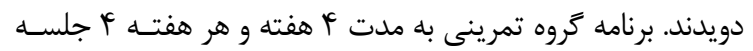

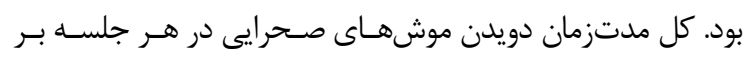

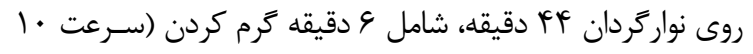

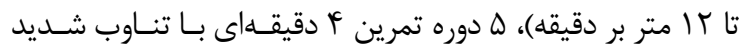

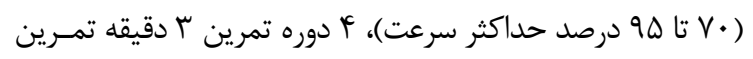

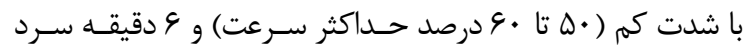
كردن (سرعت • ا تا با متر بر دقيقه) بود. شيب نـوارگردان صـفر

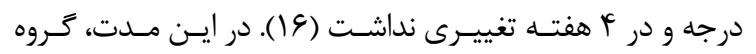




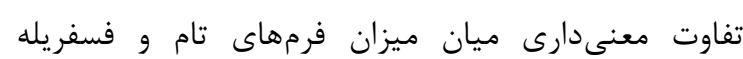
يروتئين هاى AKT1

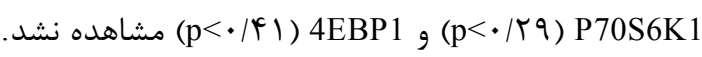

\section{بحث}

نتايج تفاوت معنى دارى را به دنبال ع هفته تمرين HIIT بين

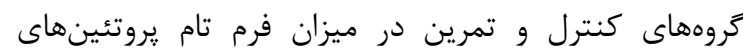

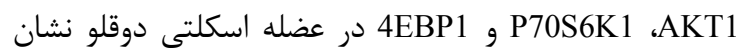
نداد، اما در ميزان فرم تام يروئتين mTOR و ميزان فرم دور

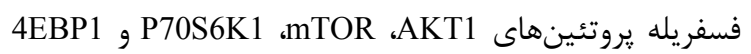
افزايش معنى دارى مشاهده شد.

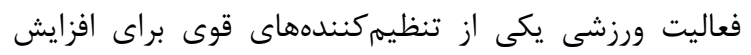

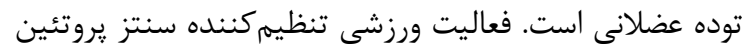

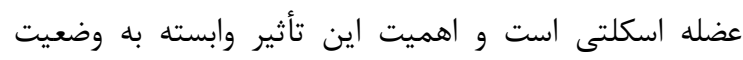

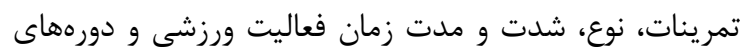
ورزش است (·r). در طول دهه كذشته بسيارى از مطالعات توصيفى نقش mTORC1 در تنظيم سنتز يروتئين عضله

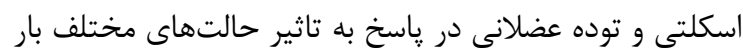

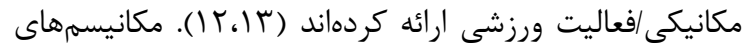

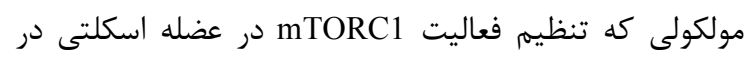

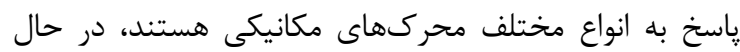

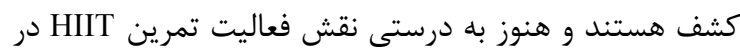

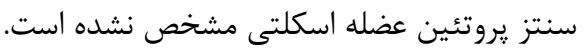
در تحقيقى فايف و همكارانش به بررسى ميزان يروتئينهاى نئن است

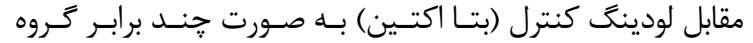
كنترل ارائه شدند (19 (1). ابتدا از آزمون كالموكروف اسميرنوف (KS) براى تعيـين نرمـاليتى

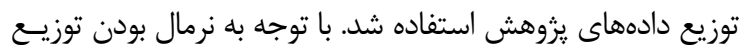

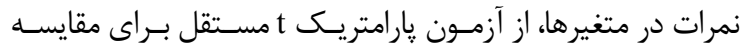

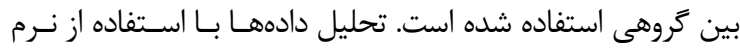

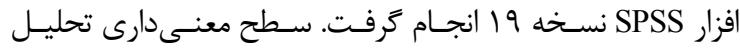

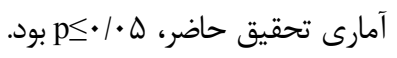

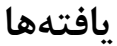

در پايان يزوهش، نتايج تحقيق حاضر نشان داد كه به دنبال

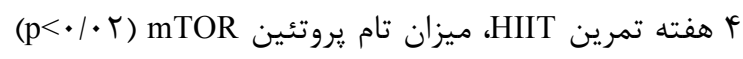

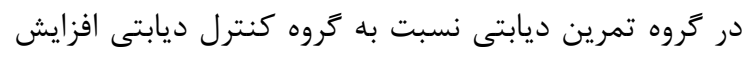

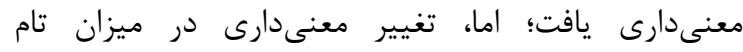

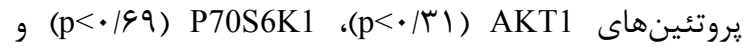

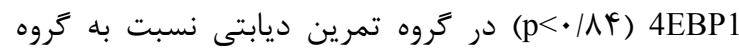

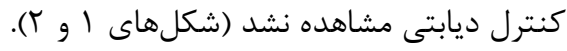

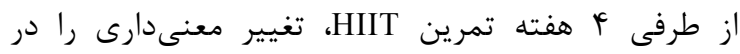

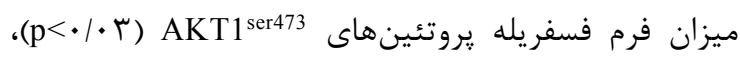

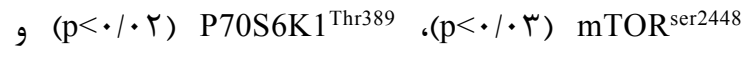
4EBP1 $1^{\mathrm{Thr37} / 46}$

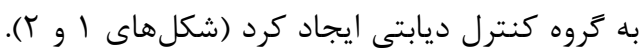

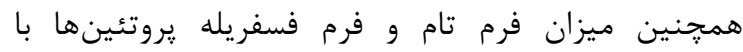

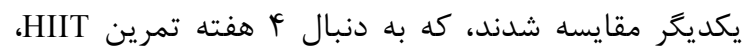
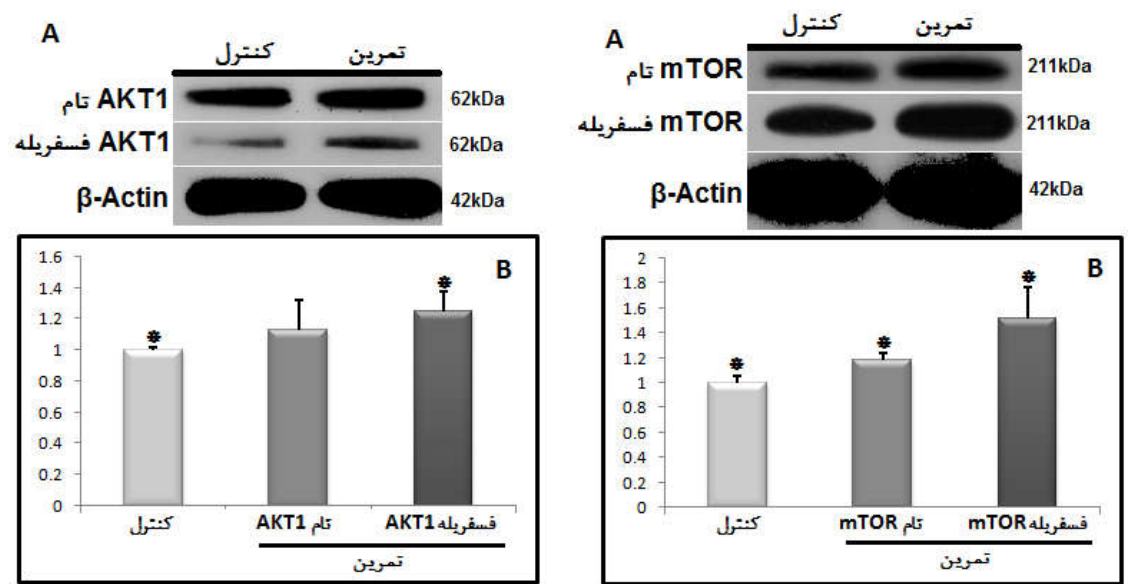

شكل ا. مقايسه ميزان فرم تام و فسفريله يروتئينهاى AKT1 و ATOR در گروههاى مورد مطالعه. A A تصاوير ايمونوبلاتينگ يروتئينهاى

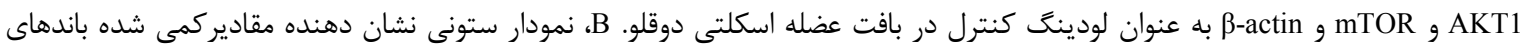

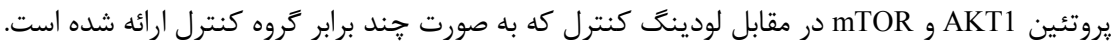
* وجود تفاوت معنى دارى كروه تمرين نسبت به كروه كنترل. 

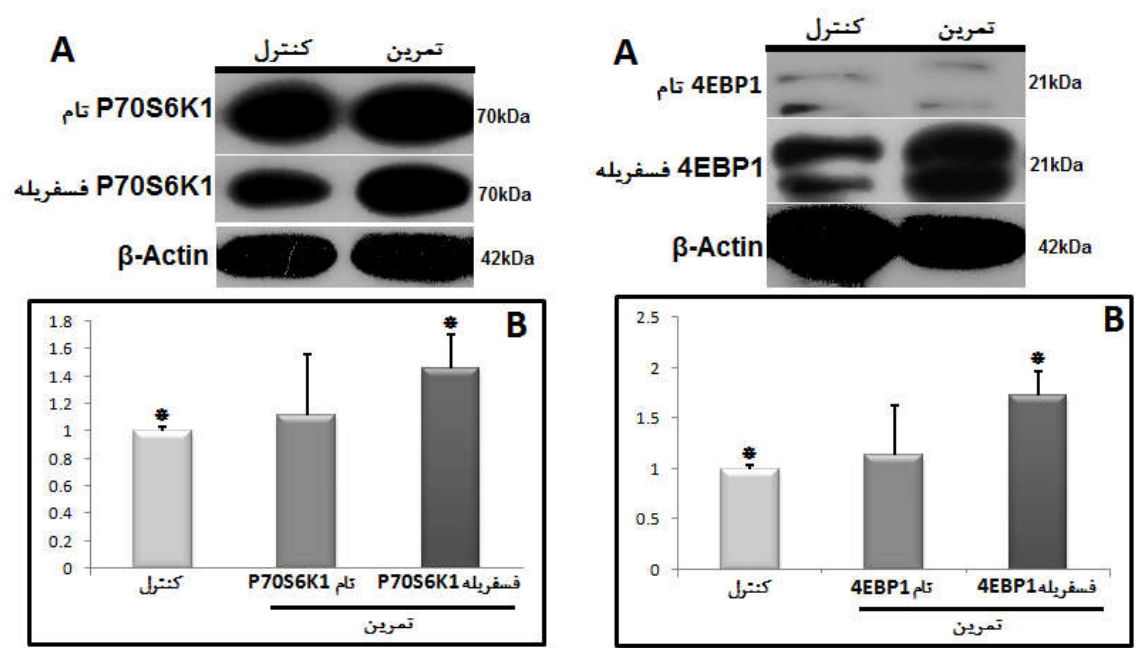

شكل r. مقايسه ميزان فرم تام و فسفريله يروتئينهاى P70S6K1 و AEBP1 در گروههاى مورد مطالعه. A، تصاوير ايمونوبلاتينگ

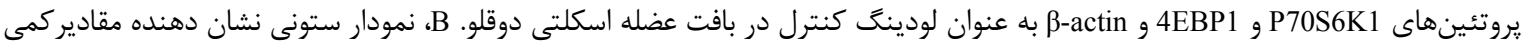

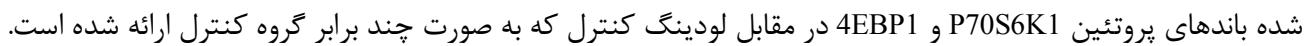
* وجود تفاوت معنى دارى گروه تمرين نسبت به كروه كنترل.

مىتواند از طريق دو مسير AKT1/mTOR/P70S6K1 و AKT1/mTOR/4EBP1

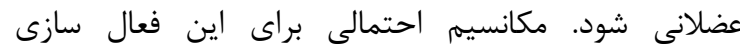
فعالشدن يروتئين AKT است كه از طريق دو سازوكار كميلكس mTORC1 را فعال مى كند. يك سازوكار از طريق فسفريلاسيون مهارى كميلكس r توبروز اسكلروزيس (TSC2) است. TSC2 مهار شده به وسيله AKT باعث مسدود كردن

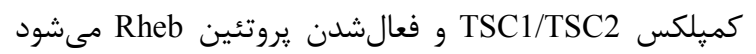
كه اين فرآيند منجر به فعالسازى كميلكس

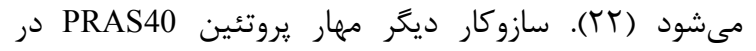

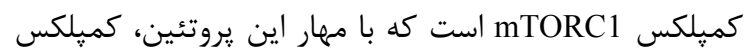

mTORC1 در تحقيقى ديگر ساتو و همكارانش به بررسى ميزان فرمهاى تام و فسفريله يروتئينهاى AKT و

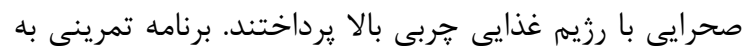

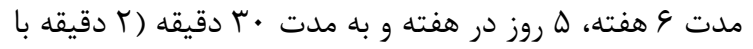

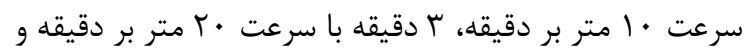
ه دقيقه با سرعت FF متر بر دقيقه با شيب صفر درجه) انجام شد. نتايج، افزايش معنىدارى را در فرم تام يروتئين AKT و فرم فسفريله يروتئين mTOR نشان داد و در فرمهاى سئيني فسفريله AKT و فرم تام يروتئين mTOR تغيير معنى وجود نداشت (r)). نتايج اين تحقيق در ارتباط با فرم فسفريله يروتئين mTOR با نتايج تحقيق حاضر همراستا است. با توجه به نتايج تحقيق ساتو و همكارانش و يافتههاى ما به به نئ نئ
P70S6K1 mTOR و 4EBP1 به دنبال سه نوع برنامه تمرينى

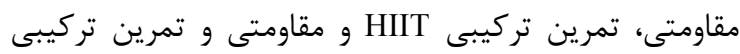

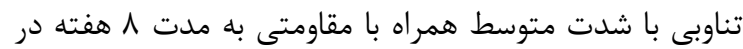

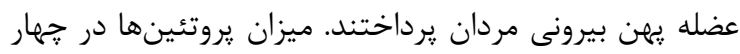

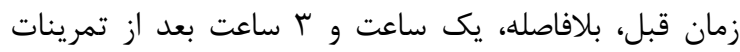
ورزشى اندازهگيرى شد. ميزان يروتئين mTOR در تمرينات

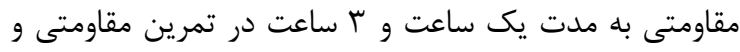

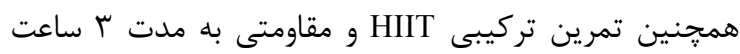
افزايش معنىدارى را نسبت به زمان قبل از تمرين ورزشى دمى دمئى نشان داد و در ديخر زمانها تغيير معنى دارى را نشان نداد. ندان.

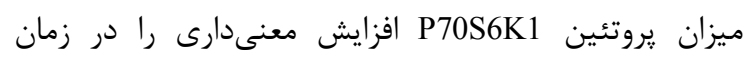
بلافاصله در زروه تمرين تركيبى HIIT و مقاومتى، زمان يكى مدين

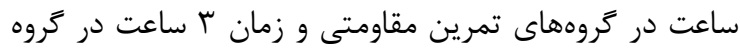

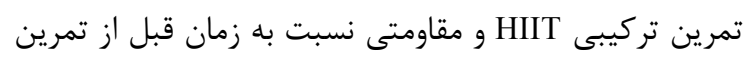

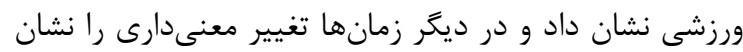

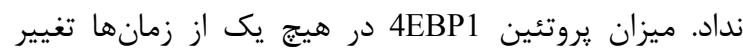
معنى دارى را نشان نداد (Y) (Y). نتايج تحقيق فايف و همكارانش نشان مىدهد تمرين مقاومتى و HIIT در بعضى از زمانها منجر به افزايش ميزان ثروتئينهاى mTOR، P70S6K1 شده است، كه اين نتايج با نتايج تحقيق حاضر در ميزان فرم تام و

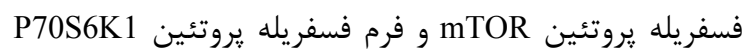
همراستا است. اما بر خلاف نتايج تحقيق فايف و همكارانش، ميزان يروتئين 4EBP1 در تحقيق حاضر افزايش معنىىارى يافت. بنابراين مىتوان كفت كه در تحقيق حاضر تمرين HIIT 
يروتئينهاى تحقيق حاضر همعَى افزايش معنىدارى را نشان دادند كه اين نشان دهنده افزايش سنتز يروتئين درون عضله اسكلتى دوقلو در آزمودنىهاى مبتلا به ديابت نوع ب است دين. در كل مهممترين تأثير مسيرهاى ثيامرسانى mTORC1 اثر بر يروتئينهاى دركير در كنترل ترجمه يعنى يروتئينهاى P70S6K1 و P70S6K1 باعث سنتز يروتئين در ريبوزوم مىشود (Y^). در تحقيق حاضر ميزان يروتئينهاى P70S6K1 و معنى دارى را به دنبال \& هفته تمرين HIIT در عضله دوان دوقلو نشان داد؛ بنابراين تمرين HIIT در عضله اسكلتى دوقلو افراد

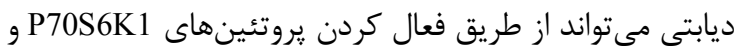

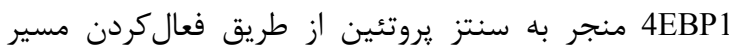
MTORC1 احتمالاً جهار هفته تمرين HIIT در عضله دوقلو موجب

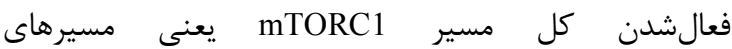
AKT/mTOR/P70S6K1 كه نشان دهنده اين مطلب است كه تمرين HIIT مىتواند در آزمودنى هاى مبتلا به ديابت منجر به بهبود سنتز يروتئين از

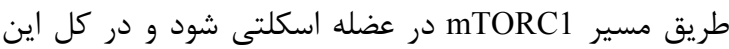
فعالسازى مسير mTORC1 مى mواند از آتروفى عضلانى در اين آزمودنى ها جلوكيرى كند.

\section{تقدير و تشكر}

اين يزوهش حاصل تلاش نويسندكان اين تحقيق است كه در دانشگاه علوم يزشكى شيراز انجام شد. از تمامى افرادى كه در لـ

$$
\text { اين امر مهمم ما را يارى كردند، تشكر مئشود. }
$$

نظر مىرسد مسير اصلى براى فعالشدن كميلكس mTORC1

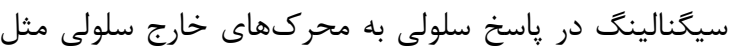
انسولين، فاكتور رشد شبه انسولين-1، فاكتور رشد ايى درمال و فاكتور رشد فيبروبلاست است. اما سازوكار فعالشدن كميلكس رئس از طريق يروتئين AKTORC1 اين گونه است كه با تحريك انسولين، سوبستراى - 1-گيرنده انسولين (IRS-1) در ناحيه تيروزين فسفريله مىشود و اين امر باعث فعالشدن سين

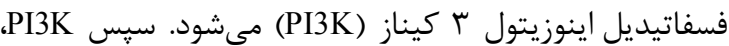

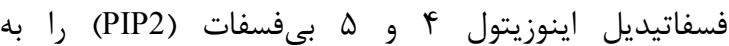
فسفاتيديل اينوزيتول س، أ و ه ترى فسفات (PIP3) تبديل مى كند. PIP3 موجب فعالشدن AKT و در نهوريت نهايت AKT

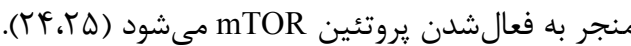
در تحقيقى ديگر تاروم و همكارانش به بررسى تاثير تحريك الكتريكى (نوعى انقباض عضلانى از طريق جريان الكتريسته) بر ميزان فرم تام يروتئينهاى mTOR، و و P70S6K1 يرداختند. در اين تحقيق ميزان تام ڤيروتئينهاى mTOR و 4EBP1

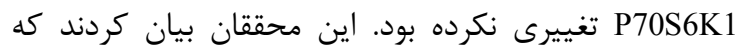
تحريك الكتريكى عضله مىتواند نوعى از فعاليت ورزشى باشد

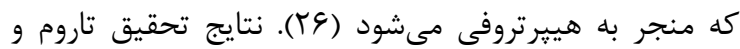

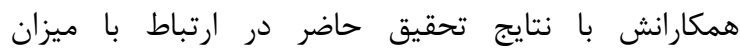
يروتئينهاى mTOR و P70S6K1 همراستا و در ارتباط با

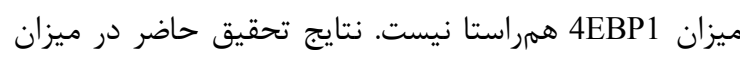

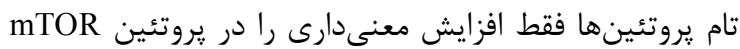
نشان داد و در ميزان ديخر يروتئينها تغيير معنى :مارى مشاهده نشد. اما شايان ذكر است كه ميزان فرم فسفريله

\section{REFERENCES}

1. Breen L, Phillips SM. Skeletal muscle protein metabolism in the elderly: interventions to counteract the anabolic resistance of ageing. Nut Metabol 2011; 8:1-11.

2. Panahi S, Agha-Alinejad H, Gharakhanloo R, Fayazmilani R, Hedayati M, Safarzadeh A, et al. The effect of 4 weeks resistance training on Murfl gene expression and muscle atrophy in diabetic Wistar rats. Med J Tabriz Uni Med Sciences Health Services 2016; 38:6-13. [In Persian]

3. Laplante M, Sabatini DM. mTOR signaling in growth control and disease. Cell 2012; 149: 274-93.

4. Patursky-Polischuk I, Kasir J, Miloslavski R, Hayouka Z, Hausner-Hanochi M, Stolovich-Rain M, et al. Reassessment of the role of TSC, mTORC1 and microRNAs in amino acids-meditated translational control of TOP mRNAs. PloS one 2014; 9:e109410.

5. Menon S, Dibble CC, Talbott G, Hoxhaj G, Valvezan AJ, Takahashi H, et al. Spatial control of the TSC complex integrates insulin and nutrient regulation of mTORC1 at the lysosome. Cell 2014; 156:771-85.

6. Showkat M, Beigh MA, Andrabi KI. mTOR signaling in protein translation regulation: implications in cancer genesis and therapeutic interventions. Mol Biol Int 2014; 1-14.

7. Cassidy S, Thoma C, Houghton D, Trenell MI. High-intensity interval training: a review of its impact on glucose control and cardiometabolic health. Diabetologia 2017; 60:7-23. 
8. Lane MT, Herda TJ, Fry AC, Cooper MA, Andre MJ, Gallagher PM. Endocrine responses and acute mTOR pathway phosphorylation to resistance exercise with leucine and whey. Biol Sport 2017; 34:197-203.

9. Nazari M, Gholamrezaei S, Shabani R. Effect of a period circuit resistance training on components of the metabolic syndrome in females with type II diabetes. Iran J Endocrinol Metabol 2016; 17:362-370.

10. Chavanelle V, Boisseau N, Otero YF, Combaret L, Dardevet D, Montaurier C, et al. Effects of high-intensity interval training and moderate-intensity continuous training on glycaemic control and skeletal muscle mitochondrial function in db/db mice. Sci Reports 2017; 7:204.

11. Ostler JE, Maurya SK, Dials J, Roof SR, Devor ST, Ziolo MT, et al. Effects of insulin resistance on skeletal muscle growth and exercise capacity in type 2 diabetic mouse models. Am J Physiol-Endocrinol Metabol 2014; 306:E592-605.

12. Edman S, Söderlund K, Blomstrand E. PO-260 Anabolic signalling in individual muscle fibres following resistance exercise in combination with amino acid intake. Exerc Biochem Rev 2018; 1:260.

13. Camera DM, Edge J, Short MJ, Hawley JA, Coffey VG. Early time course of Akt phosphorylation after endurance and resistance exercise. Med Sci Sports Exerc 2010; 42:1843-52.

14. Safhi MM, Anwer T, Khan G, Siddiqui R, Moni Sivakumar S, Alam MF. The combination of canagliflozin and omega-3 fatty acid ameliorates insulin resistance and cardiac biomarkers via modulation of inflammatory cytokines in type 2 diabetic rats. Korean J Physiol Pharmacol 2018; 22:493-501.

15. Khalili A, Nekooeian AA, Khosravi MB. Oleuropein improves glucose tolerance and lipid profile in rats with simultaneous renovascular hypertension and type 2 diabetes. J Asian Nat Prod Res 2017; 19:1011-21.

16. Fallahi A, Gaeini A, Shekarfroush S, Khoshbaten A. Cardioprotective effect of high intensity interval training and nitric oxide metabolites (NO2-, NO3-). Iran J Public Health 2015; 44:1270-6.

17. Garcia NF, Sponton AC, Delbin MA, Parente JM, Castro MM, Zanesco A, et al. Metabolic parameters and responsiveness of isolated iliac artery in LDLr-/-mice: role of aerobic exercise training. Am J Cardiovasc Dis 2017; 7:64.

18. Zarei F, Shadmehri S, Daryanoosh F, Sherafati Moghadam M, Mahmoodi M T. The effect of eight weeks of highintensity interval training (HIIT) on the serum levels of chemerin, omentin-1 and apelin on overweight female SpragueDawley rats. JSSU 2018; 26:473-482.

19. Khani M, Motamedi P, Dehkhoda MR, Nikukheslat SD, Karimi P. Effect of thyme extract supplementation on lipid peroxidation, antioxidant capacity, PGC- $1 \alpha$ content and endurance exercise performance in rats. J Int Soc Sports Nutr 2017; 14: 1-8.

20. Burd NA, Tang JE, Moore DR, Phillips SM. Exercise training and protein metabolism: influences of contraction, protein intake, and sex-based differences. Eur J Appl Physiol 2009; 106:1692-701.

21. Fyfe JJ, Bishop DJ, Bartlett JD, Hanson ED, Anderson MJ, Garnham AP, et al. Enhanced skeletal muscle ribosome biogenesis, yet attenuated $\mathrm{mTORC} 1$ and ribosome biogenesis-related signalling, following short-term concurrent versus single-mode resistance training. Sci Rep 2018; 8:560-1-21.

22. Wallace MA, Hughes DC, Baar K. mTORC1 in the Control of Myogenesis and Adult Skeletal Muscle Mass. Molecules to Medicine with mTOR 2016;7: 37-56.

23. Sato S, Kataoka S, Sato M, Takahashi A, Norikura T, Mukai Y. Effect of Bangle (Zingiber purpureum) extract and low-intensity exercise on mTOR phosphorylation and autophagy flux in skeletal muscles of rats on a high-fat diet. $\mathrm{J}$ Funct Food 2018; 47:554-61.

24. Saxton RA, Sabatini DM. mTOR signaling in growth, metabolism, and disease. Cell 2017; 168:960-76.

25. Laplante M, Sabatini DM. mTOR signaling. Cold Spring Harb Perspect Biol 2012; 4: a011593.

26. Tarum J, Folkesson M, Atherton PJ, Kadi F. Electrical pulse stimulation: an in vitro exercise model for the induction of human skeletal muscle cell hypertrophy. A proof $\square$ of $\square$ concept study. Exp Physiol 2017; 102:1405-13.

27. Ci Y, Shi K, An J, Yang Y, Hui K, Wu P, et al. ROS inhibit autophagy by downregulating ULK1 mediated by the phosphorylation of p53 in selenite-treated NB4 cells. Cell Death Dis 2014; 5: 1-10.

28. Datan E, Shirazian A, Benjamin S, Matassov D, Tinari A, Malorni W, et al. mTOR/p70S6K signaling distinguishes routine, maintenance-level autophagy from autophagic cell death during influenza A infection. Virology 2014; 452: 175-90. 